\title{
Glacial Area Changes in the Ili River Catchment (Northeastern Tian Shan) in Xinjiang, China, from the 1960s to 2009
}

\author{
Junli Xu, ${ }^{1,2}$ Shiyin Liu, ${ }^{1}$ Wanqin Guo, ${ }^{1}$ Zhen Zhang, ${ }^{1,2}$ Junfeng Wei, ${ }^{1,2}$ and Tong Feng ${ }^{1,2}$ \\ ${ }^{1}$ State Key Laboratory of Cryospheric Sciences, Cold and Arid Regions Environmental and Engineering Research Institute (CAREERI), \\ Chinese Academy of Sciences, Lanzhou 730000, China \\ ${ }^{2}$ University of Chinese Academy of Sciences, Beijing 100049, China
}

Correspondence should be addressed to Junli Xu; xujunli05@lzb.ac.cn and Shiyin Liu; liusy@lzb.ac.cn

Received 18 December 2014; Revised 27 April 2015; Accepted 30 April 2015

Academic Editor: Charles Jones

Copyright (C) 2015 Junli Xu et al. This is an open access article distributed under the Creative Commons Attribution License, which permits unrestricted use, distribution, and reproduction in any medium, provided the original work is properly cited.

\begin{abstract}
The Ili River originates in the Tian Shan Mountains of Northwest China before flowing into Kazakhstan and Lake Balkash. Melting snow and ice are its major contributors. We analyzed glacial changes in the upper Ili River basin between the 1960s and 2007/2009 using topographic maps and satellite imagery from a Landsat TM. The relationships between glacial changes and glacial size, topographic factors, and debris cover were examined. Our results found that total glacial area decreased by $485 \pm 177.3 \mathrm{~km}^{2}(24.2 \%$ $\pm 8.8 \%$ ) during the study period, and there were no advancing glaciers. Additionally, 331 glaciers disappeared and 18 disintegrated into two or three smaller glaciers. This study demonstrated a linear relationship between glacial area change and elevation. Changes in glaciers smaller than $1 \mathrm{~km}^{2}$ were affected by both glacial size and topographic factors, while larger ones were affected by size only. Area losses in debris-covered glaciers were smaller by $2.5 \%$ to $7.5 \%$ compared to clean ice of the same size in this basin. As in other glaciated regions, glacial retreat in the Ili River basin is attributed to global warming. The slightly increasing precipitation over the study period could not offset the ice melting.
\end{abstract}

\section{Introduction}

The Intergovernmental Panel on Climate Change (IPCC) reported that alpine glaciers respond to regional climate over a period of decades and thus serve as indicators of regional climate change [1]. Most alpine glaciers in the world have shown shrinkage in area since the later part of the 19th century, as did the glaciers in the Tian Shan Mountains [13]. However, advancing or surging glaciers were found in the Karakoram Himalaya, northwestern Himalaya, and Qilian mountains during the same period [4-6].

Global-warming-induced snow and ice losses from the cryosphere impact socioeconomic development because rising sea levels cause coastal flooding, melting glaciers cause flooding from rapid melting and glacial lake outburst, and glacial shrinkage reduces a dependable irrigation supply [710]. Cryosphere-related disasters such as glacier/snow melt floods, glacial lake outburst floods, ice jam floods, and avalanches have frequently been observed in the Tian Shan region [11]. In these mountains, hazards related to drifting snow, avalanches, ice jam floods, and glacial melt floods have occurred [11, 12]. There were no reports of glacial lake outburst floods in the study area, and many glacial lakes continue to expand in the Ili River basin as a result of glacial melting [13]. Thus, it is important to know how glaciers have changed in this area. However, there has been little research to quantify the actual changes to glaciers $[14,15]$.

Changes in length, area, thickness, and volume in response to temperature and precipitation changes are not uniform across the glaciers over periods of years to decades $[6,16-19]$. This variable pattern of responses to climate changes is expected to be affected by glacial size and topographic factors. Glaciers that are smaller in area experience greater shrinkage [16-18]. However, there is no information about the relationship between glacial changes and topographic factors. In addition, there is seemingly conflicting research regarding the influence that debris cover plays on changes to glacial surface elevation, area, and length [20,21]. There are debris-covered glaciers with no visible or only little area changes but significant mass changes. 


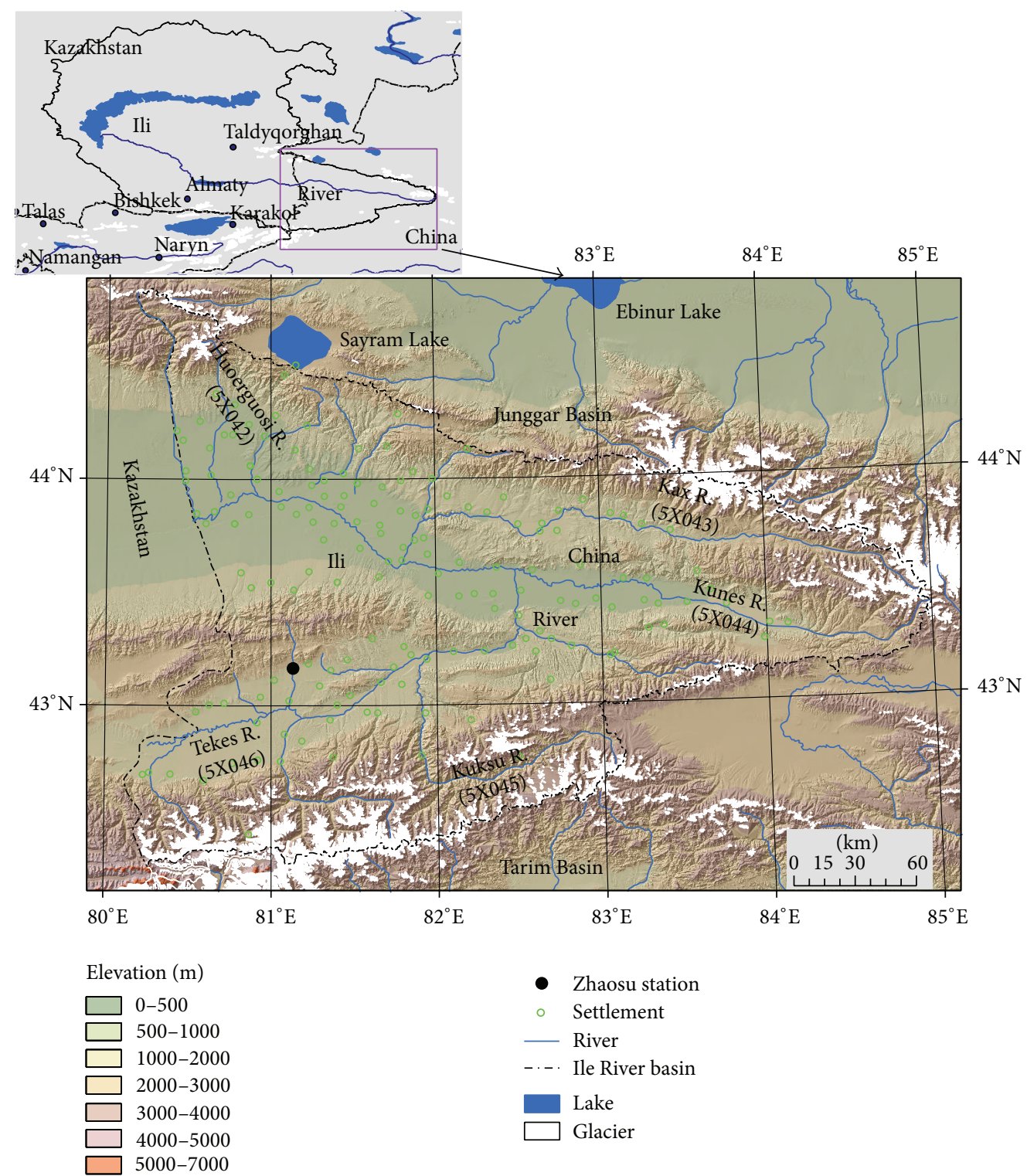

FIGURE 1: Glaciated areas in the Ili River basin.

Glaciers in the Ili River watershed have a wide range of surface areas, elevations, and debris covers. This examination of changes in the Ili River basin's glaciers, from the 1960s to 2009, used topographic maps and satellite imagery from the Landsat Thematic Mapper (TM) to document glacial size, topographic factors affecting glacial area changes, and the amount of debris cover.

\section{Study Area}

The Ili River, originating in the central northwest Tian Shan Mountains and flowing from China into Kazakhstan (Lake Balkhash), is fed by melting snow and ice [22]. Its total drainage area is $4.2 \times 10^{5} \mathrm{~km}^{2}$, including both the Chinese and Kazakhstan sections. Because this region lies on the west side of the mountains, it receives more precipitation than other parts of the Tian Shan Mountains; its westward opening allows westerly uplift [22]. Precipitation at the yearround snow line is around $800-1000 \mathrm{~mm}$ per year. Snowfall, during the winter and spring, accounts for $40 \%-50 \%$ of the annual precipitation [22]. This is different from other glaciated areas in the Tian Shan Mountains where most of the precipitation occurs during summer. Although the Ili River is mostly in Kazakhstan, 77.5\% of the glaciers that feed it are in China [23]. Our study focused on the glaciers within China (Figure 1). The World Glacier Inventory (http://nsidc.org/ data/docs/noaa/g01130_glacier_inventory/) has coded the Ili River basin as 5X04 with five tributary basins originating in China (5X042, 5X043, 5X044, 5X045, and 5X046). The first Ili River basin glacier inventory, performed in the 1960s, found 2373 glaciers totaling $2022.66 \mathrm{~km}^{2}$ and occupying 
TABLE 1: Topographic maps list for the study area.

\begin{tabular}{lcc}
\hline Sources & Year & Quantity \\
\hline & 1959 & 2 \\
$1: 50,000$ & 1962 & 2 \\
topographic maps & 1964 & 12 \\
& 1966 & 2 \\
\hline & 1959 & 2 \\
$1: 100,000$ & 1962 & 2 \\
topographic maps & 1964 & 1 \\
& 1966 & 3 \\
& 1968 & 1 \\
\hline
\end{tabular}

an estimated $127.96 \mathrm{~km}^{3}$ in China [24]. Snow line elevations ranged from 3630 to $3840 \mathrm{~m}$ above sea level (m asl).

\section{Dataset and Methodology}

3.1. Glaciers in the 1960s. The first Chinese inventory of glaciers (FCI) was compiled using primarily topographic maps scaled at $1: 50,000$ or $1: 100,000$. There were few glaciers from maps scaled at $1: 1,000,000$ because of the data quality [22]. Although glacier boundaries were manually corrected using $1: 43,000$ and $1: 60,000$ aerial photographs and analytic photogrammetric methods [22], notable errors remained in the mapped delineation of glaciers. No vectorized glacier boundaries were included in this inventory compilation. Instead, glacier boundaries were determined from attribute tables or by manually measuring the areas on maps. We reexamined the early maps depicting the glaciers at scales of $1: 50,000$ and $1: 100,000$ (Table 1). Where the first Chinese inventory used maps scaled at 1:1,000,000, we employed three Landsat Multispectral Scanner (MSS) satellite images instead. These early maps, from between 1959 and 1968, were produced with photogrammetric methods by the Chinese Military Geodetic Service. The MSS images were acquired by the United States Geological Survey (USGS) in 1972 and 1977 from the National Aeronautics and Space Administration, orthorectified at level 1T. During this study, these maps were first scanned at a resolution of 300 dots per inch and then two-dimension georeferenced and rectified using a global coordinate grid to remove the geometric distortion acquired during long-term storage. Using ERDAS Imagine 9.1 software, these maps were georeferenced to the mapping coordinates of the 1954 Beijing Geodetic Coordinate System geoid, known as BJ54, and the datum level was the Yellow Sea mean sea level at Qingdao Tidal Observatory. These maps were then transposed into the Universal Transverse Mercator coordinate system referenced to the World Geodetic System 1984 ellipsoidal elevation (WGS84) using a seven-parameter transformation. Shifts and deformations occurred between BJ54 and the WGS84 coordinate systems in both the eastwest direction and north-south direction [25]. Detailed information from the seven-parameter transformation was shown by Wang et al. [26]. The seven parameters of each map were calculated utilizing national trigonometric reference points. Errors introduced by this method were shown to be no greater than 0.5 meters $[6,27,28]$. The Landsat MSS images were orthorectified by USGS using the Universal Transverse Mercator coordinate system referenced to the WGS84 ellipsoidal elevation. Finally, glacier boundaries on maps and MSS images were digitized manually into a shape file format using ArcMap software. Glaciers were white and easy to distinguish from other surface features in bands 4,3 , and 2 of the composite MSS images. Glaciers that measured at least $0.01 \mathrm{~km}^{2}$ were included in this study. Detailed information was found in 1:50,000 topographic maps for $30 \%$ of the glaciers, in 1:100,000 maps for $35 \%$ of the glaciers, and in MSS images for the remaining $35 \%$ of the glaciers, which were larger than $2 \mathrm{~km}^{2}$. These glaciers formed the basic data for the changes in glaciers in the source region of the Ili River.

3.2. Glaciers in 2007 and 2009. To develop new glacier inventories and up-to-date satellite images of the Ili River watershed, this study acquired eight Landsat TM scenes from the USGS (https://lpdaac.usgs.gov/get_data/) that had spatial resolutions of 30 meters (Table 1). All Landsat scenes were orthorectified in level 1T by the USGS using global ground control points (GCPs) from Global Land Survey 2005 datasets. The GCP report files for TM images were available, but those for MSS images were not. Table 2 shows the GCP residuals, which have a maximum of $4.6 \mathrm{~m}$ and a mean of $4.1 \mathrm{~m}$. Where there were no GCP files for MSS data, we compared tie points of MSS images with TM images to assess the accuracy. The mean error was $13.2 \mathrm{~m}$.

Methods for glacier mapping using Landsat data include (1) manual delineation of glacier outlines on false color image composites [16, 29], (2) segmentation of ratio images with reflectance thresholds [30], (3) the normalized-difference snow index (NDSI) [31, 32], and (4) supervised classification techniques [33]. In this study, ratio images of the raw digital numbers from TM band 3 and TM band 5 with a threshold of 2.1 were used to obtain a surface mask for the glaciers in the Ili River basin. This thematic method has been commonly used and proven to be effective for extracting glacial information $[30-32,34]$. The drawbacks of this method are its inability to identify glacier debris cover and its inability to determine portions of the glaciers covered by debris, which must be done by manual digitizing. Current automatic methods for delineating glacier debris cover continue to need manual modifications [35-38]. For the 80 glaciers in the Ili watershed that had debris covering their terminus areas, manual delineation with Landsat TM was applied to extract debris boundaries. Manual digitization of debriscovered glaciers was based mainly on the recognition of distinctive surface features such as supraglacial lakes and differences in colors and textures of the glacial surface in various red-green-blue composites of Landsat images. These special features made it easier to differentiate debris from surrounding periglacial landforms [39]. This manual digitization was performed by experienced glaciologists. The debris terminal ended at the outlets of subglacial streams near glacial termini. Finally, the resultant contiguous ice coverage was further divided into individual glacier polygons, 
TABLE 2: Landsat images list for the study area.

\begin{tabular}{lcccc}
\hline Satellite & Path & Row & Acquisition date $(\mathrm{yy}-\mathrm{mm}$-dd) & Tie points/GCP residual (m) \\
\hline \multirow{3}{*}{ Landsat MSS } & 156 & 30 & $1972-10-8$ & 15.2 \\
& 157 & 30 & $1977-8-18$ & 13.1 \\
& 158 & 30 & $1977-8-18$ & 11.2 \\
& 144 & 30 & $2009-8-8$ & 4.0 \\
& 145 & 29 & $2007-9-11$ & 4.0 \\
Landsat 5 TM & 145 & 30 & $2007-9-11$ & 4.2 \\
& 146 & 31 & $2007-9-18$ & 4.6 \\
& 146 & 29 & $2007-9-18$ & 4.1 \\
& 147 & 30 & $2009-8-13$ & 4.2 \\
& 147 & 31 & $2007-9-25$ & 3.9 \\
\end{tabular}

based on topographical ridgelines, using ASTER GDEM data (http://gdem.ersdac.jspacesystems.or.jp/) [40].

The debris cover percentage used hereinafter was calculated based on current glaciers. Our purpose was not to study the changes of debris cover; thus the debris cover area in the 1960s was not extracted.

\section{Error Assessment}

Two methods are used to assess the error in measurements of glacial changes: one based primarily on image resolutions and coregistration accuracies of multi-images [41] and the other on calculating the uncertainty of glacial data using given buffers $[42,43]$. The latter was applied in this study because the former lacks assessment of errors in the debris-covered areas.

The 1960s glaciers were extracted from topographic maps and Landsat MSS images. Thus, the uncertainty which arises during glacial boundary delineation needed to be assessed in terms of the accuracy of both map data and MSS images. In topographic maps, the accuracy of glacial boundary delineation is dependent on scanning resolution, map quality, and map scales. Previous research demonstrated that the accuracy of these maps can be further confirmed using data from a global positioning satellite (GPS) [25, 44]. However, instead of using GPS data, we used the root mean square of geometrical corrections and the digitizing accuracy to confirm glacier boundaries. The root mean square for each map was calculated from ground control points (GCPs), and mean errors of $4.2 \mathrm{~m}$ and $9.8 \mathrm{~m}$ were found for the $1: 50,000$ and $1: 100,000$ maps, respectively. When digitizing maps, the error is around one pixel, or $5 \mathrm{~m}$ and $10 \mathrm{~m}$ for the 1:50,000 and $1: 100,000$ maps, respectively [45]. We applied the law of error (1) and found that the total errors were $6.5 \mathrm{~m}$ and $14.2 \mathrm{~m}$ for the $1: 50,000$ and $1: 100,000$ maps, respectively

$$
\sigma=\sqrt{\sigma_{1}^{2}+\sigma_{2}^{2}}
$$

In satellite images, the main factors that cause uncertainty in glacier delineation include cloud and snow cover, the sensor spatial resolution, and mountain shadows $[6,43,46]$. Moreover, extracting glacier boundaries also brings about errors $[34,47]$. No images with clouds and seasonal snow were used in our study except for one MSS image that showed a $1 \%$ cover of seasonal snow. We modified the shadow areas using images from Google Earth by the Export to KML tool. In addition, the method of segmentation using TM band 3 and TM band 5 could also partially discern shadows [32]. After we performed these corrections, hindrances from clouds, snow, and shadows became negligible. Accuracy of less than onehalf pixel was usually achievable for glaciers without debris, cloud, and seasonal snow cover [42]. Thus, we determined the uncertainty to be $28.5 \mathrm{~m}$ for Landsat MSS images and $14.3 \mathrm{~m}$ for TM images in clean ice areas. However, the error caused by debris cover was larger [39]. Our partner compared the debris boundary with GPS points and found that the error in debris-covered ice was $31.3 \mathrm{~m}$ in Landsat TM images [48], which is nearly one pixel. Thus, a one-pixel buffer was used for debris-covered glaciers in TM images and $57 \mathrm{~m}$ for glaciers in MSS data. This analysis determined an uncertainty of $7.6 \%$ for glaciers mapped using data from the 1960 s and $6 \%$ for glaciers mapped using TM data from 2007 and 2009.

\section{Results}

5.1. Glaciers in the 1960s. The first inventory of glaciers, which took place in the 1960s, found 2373 glaciers with a total glacial area of $2022.7 \mathrm{~km}^{2}$. Our more accurate study of the $1960 \mathrm{~s}$ maps resulted in identification of 2119 glaciers with a total area of $2002.9 \pm 152.2 \mathrm{~km}^{2}$. Details of the differences are shown in Table 3. The large difference in both glacier numbers and areas as a result of this update is probably a consequence of error in the 1:1,000,000 maps that were used by the FCI. Some glacial areas were likely missed while some seasonal snow was mistaken for glacier ice. There are no other data available to validate the accuracy of the FCI, and we used both the topographic maps and MSS to cross-validate the glaciers found in the 1960s. The biggest difference was found in the area of glacier 5X046G0048, which had originally been inaccurately measured to be $36.5 \mathrm{~km}^{2}$ using the $1: 1,000,000$ 
TABle 3: The differences in glaciers before and after update.

\begin{tabular}{lcccc}
\hline \multirow{2}{*}{ Area $\left(\mathrm{km}^{2}\right)$} & \multicolumn{2}{c}{ Glacier before update } & \multicolumn{2}{c}{ Glacier after update } \\
& Quantity & Area & Quantity & Area \\
\hline$<0.5$ & 1662 & 317.16 & 1420 & 281.53 \\
$0.5 \sim 1$ & 316 & 219.06 & 321 & 229.35 \\
$1 \sim 2$ & 194 & 271.1 & 185 & 266.46 \\
$2 \sim 5$ & 130 & 390.46 & 123 & 375.54 \\
$5 \sim 10$ & 48 & 329.61 & 48 & 339.37 \\
$10 \sim 40$ & 21 & 402.35 & 20 & 371.05 \\
$>40$ & 2 & 92.92 & 2 & 139.64 \\
Total & 2373 & 2022.66 & 2119 & 2002.94 \\
\hline
\end{tabular}

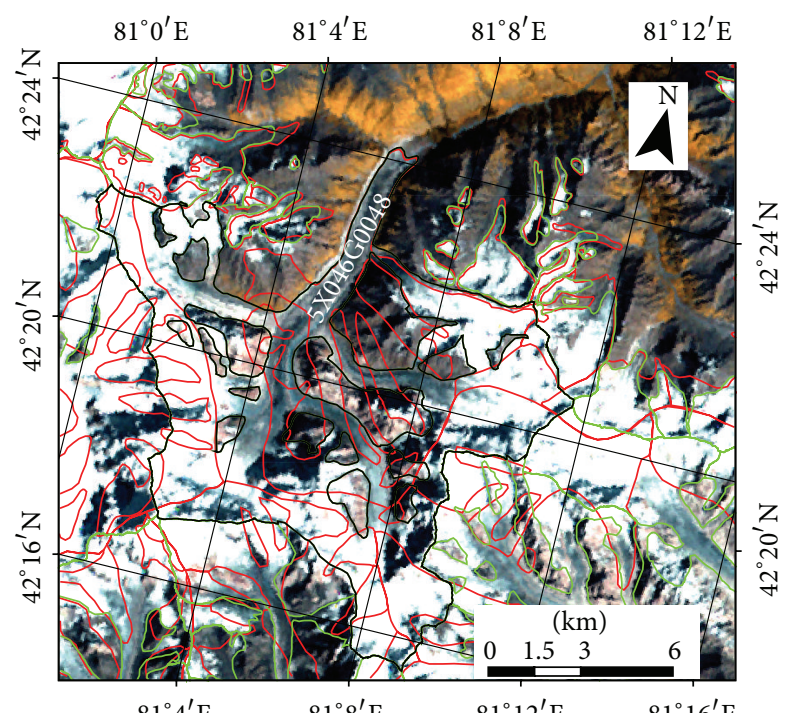

$81^{\circ} 4^{\prime} \mathrm{E}$ $81^{\circ} 8^{\prime} \mathrm{E}$

$81^{\circ} 12^{\prime} \mathrm{E}$

$81^{\circ} 16^{\prime} \mathrm{E}$

Glacier boundary in the 1960s after being updated

Glacier boundary in the 1960s before being updated

Figure 2: Glaciers in the 1960s before and after update. Glacier 5X046G0048 was in the black boundary after update.

scale maps. Using the MSS image, its area was found to be $88.9 \mathrm{~km}^{2}$ (Figure 2), making it the largest glacier in the study area. Another problem identified in the 1960s inventory was that $33.5 \mathrm{~km}^{2}$ was originally described as glacier ice, but it was actually seasonal snow. In addition, $9.3 \mathrm{~km}^{2}$ was not recognized as glacier ice.

The corrected 1960s maps showed that median glacial elevation ranged from 3158 to $4567 \mathrm{~m}$ asl (Figure 3), and the lowest elevation of a glacier's terminus was $2635 \mathrm{~m}$ asl; $97 \%$ of the total glacial area was located between 3500 and $4200 \mathrm{~m}$ asl.

In the 1960s, there were 23 glaciers in the Ili River basin larger than $10 \mathrm{~km}^{2}$. Although $96.7 \%$ of the glaciers in the basin would be considered small $\left(\leq 5 \mathrm{~km}^{2}\right)$, these made up $57.6 \%$ of the total glacial area in the basin (Table 3 ). There were only 80 debris-covered glaciers in the basin, but these glaciers accounted for $34 \%$ of the total glacial area $\left(686.7 \mathrm{~km}^{2}\right)$ and included the two largest glaciers in the basin. The surfaces of individual glaciers were $1.3 \%$ to $26.4 \%$ covered in debris.

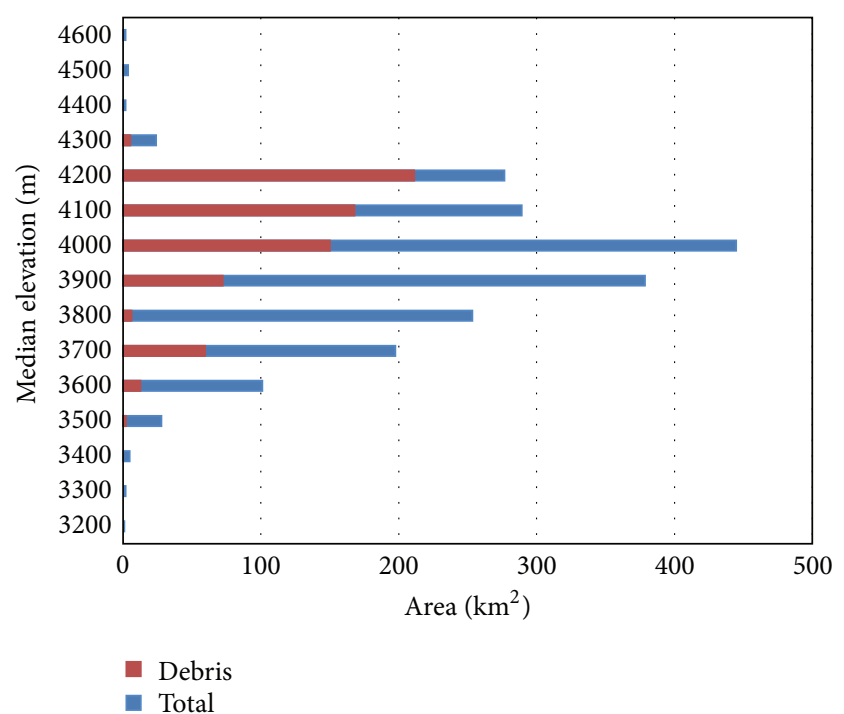

Figure 3: Proportion of glacial area covered by debris at varying elevations per 2007/2009 mapping data.

Debris covered $16.2 \%$ of the surfaces of the two largest glaciers. Most of the debris cover was found between $3500 \mathrm{~m}$ and $4300 \mathrm{~m}$ asl (Figure 3), and the peak debris area was found between 3900 and $4000 \mathrm{~m}$ asl.

5.2. Glacial Changes. When comparing glacial area from the 1960s to 2007 and 2009, we found that almost all those in the Ili River basin were receding; three small glaciers remained stable. During the same time period, the total glacial area decreased by $485 \pm 177.3 \mathrm{~km}^{2}$, or $24.2 \% \pm 8.8 \%\left(\sim 0.6 \% \cdot \mathrm{a}^{-1}\right)$. The number of glaciers decreased from 2119 in the 1960s to 1813 in the late 2000s. During the same period, the mean glacial size decreased from $0.94 \mathrm{~km}^{2}$ to $0.72 \mathrm{~km}^{2}$. The speed of glacial retreat appeared to be dependent on the subbasin in which it was located (Table 4). The most drastic shrinkages were $47.2 \% \pm 5.7 \%$ in the Kunes river subbasin and $42.6 \%$ $\pm 9.4 \%$ in the Huoerguosi River. Glaciers in the Kax River and Kuksu River subbasins experienced moderate recession rates of $27.5 \% \pm 5.0 \%$ and $29.2 \% \pm 9.0 \%$, respectively. The least amount of shrinkage, found in the Tekes River subbasin, was $18.3 \% \pm 10.8 \%$.

Between the 1960s and the late 2000s, 331 glaciers disappeared completely, and 18 glaciers disintegrated into two or three smaller glaciers. All those that disappeared were debrisfree. The area of these glaciers was $34.8 \mathrm{~km}^{2}$, accounting for $1.7 \%$ of the total glacial area in the Ili River basin. Of those that disappeared, $59.4 \%$ were smaller than $0.1 \mathrm{~km}^{2}$, $30.3 \%$ were between $0.1 \mathrm{~km}^{2}$ and $0.2 \mathrm{~km}^{2}$, and the remaining $10 \%$ were larger than $0.2 \mathrm{~km}^{2}$. A scatter plot of the median altitude versus glacial area of the disappearing glaciers is shown in Figure 4. Most were at around 3100 to $4200 \mathrm{~m}$ asl, and the median altitude decreased linearly with glacial area. Furthermore, nearly $60 \%$ of them were smaller than $0.1 \mathrm{~km}^{2}$, independent of their locations or altitudes. However, the larger ones $\left(>0.3 \mathrm{~km}^{2}\right)$ were generally at very low altitudes 
TABLE 4: Glacial area changes in five tributary subbasins of the Ili River.

\begin{tabular}{|c|c|c|c|c|c|}
\hline Drainage name (code) & Quantity & $\begin{array}{l}\text { Area in the 1960s } \\
\left(\mathrm{km}^{2}\right)\end{array}$ & $\begin{array}{l}\text { Area in } 2007 \text { and } \\
2009\left(\mathrm{~km}^{2}\right)\end{array}$ & $\begin{array}{c}\text { Mean area } \\
\left(\mathrm{km}^{2}\right)\end{array}$ & Area change (\%) \\
\hline Huoerguosi R. (5X042) & 112 & $53.17 \pm 4.7$ & $30.54 \pm 1.7$ & 0.47 & $-42.6 \pm 9.4$ \\
\hline Kax R. (5X043) & 502 & $413.86 \pm 11.4$ & $300.03 \pm 17.1$ & 0.82 & $-27.5 \pm 5.0$ \\
\hline Kunes R. (5X044) & 222 & $80.81 \pm 3.9$ & $42.68 \pm 2.4$ & 0.36 & $-47.2 \pm 5.7$ \\
\hline Kuksu R. (5X045) & 510 & $405.60 \pm 32.4$ & $287.09 \pm 16.4$ & 0.80 & $-29.2 \pm 9.0$ \\
\hline Tekes R. (5X046) & 773 & $1049.50 \pm 99.8$ & $857.61 \pm 53.5$ & 1.36 & $-18.3 \pm 10.8$ \\
\hline Total & 2119 & $2002.94 \pm 152.2$ & $1517.95 \pm 91.1$ & 0.95 & $-24.2 \pm 8.8$ \\
\hline
\end{tabular}

TABLE 5: Details regarding the 18 glaciers that disintegrated.

\begin{tabular}{|c|c|c|c|}
\hline Drainage basin name & Glacial area $\left(\mathrm{km}^{2}\right)$ & Altitude of disintegration $(\mathrm{m})$ & Area change (\%) \\
\hline \multirow{4}{*}{ Huoerguosi R. } & 2.02 & 3447 & -15.96 \\
\hline & 0.74 & 3429 & -52.77 \\
\hline & 4.04 & 3405 & -33.40 \\
\hline & 1.44 & 3474 & -51.77 \\
\hline \multirow{4}{*}{ Kax R. } & 18.79 & 3172 & -19.06 \\
\hline & 6.89 & 3385 & -21.17 \\
\hline & 6.45 & 3418 & -13.22 \\
\hline & 1.96 & 3466 & -31.77 \\
\hline \multirow{4}{*}{ Kuksu R. } & 3.91 & 3872 & -26.95 \\
\hline & 5.79 & 3804 & -13.78 \\
\hline & 1.86 & 3970 & -30.31 \\
\hline & 2.49 & 3889 & -31.44 \\
\hline \multirow{7}{*}{ Tekes R. } & 35.07 & 3015 & -8.86 \\
\hline & 2.38 & 3434 & -28.61 \\
\hline & 8.87 & 3527 & -16.31 \\
\hline & 9.70 & 3800 & -11.58 \\
\hline & 14.44 & 3665 & -10.14 \\
\hline & 88.93 & 3102 & -5.25 \\
\hline & & 3860 & \\
\hline
\end{tabular}

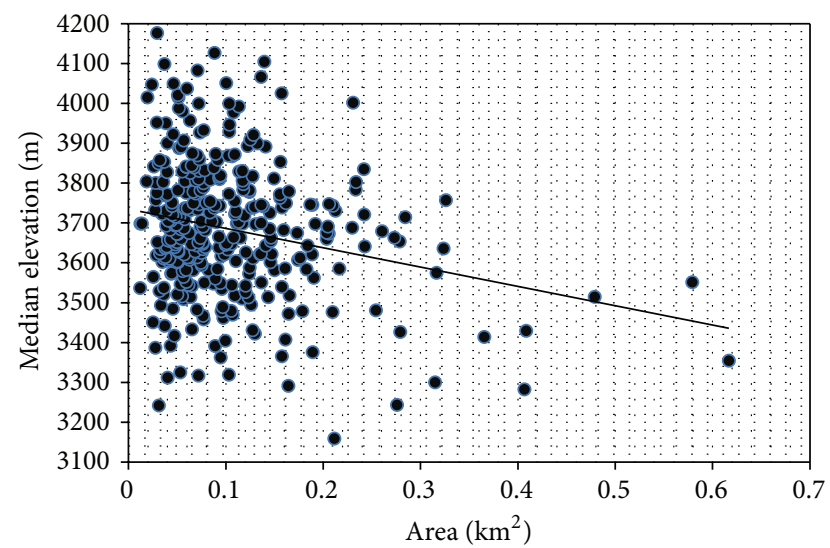

FIGURE 4: Scatter plot showing the median altitude versus area of disappearing glaciers.

(lower than $3600 \mathrm{~m}$ asl), indicating that these glaciers disappeared because of warming temperatures.
Disintegrated glaciers (Table 5), those that broke up into smaller pieces, existed in all subbasins except for the Kunes River basin. Seventeen broke up into two glaciers, and one broke up into three glaciers. Disintegration occurred at elevations between $3015 \mathrm{~m}$ and $3970 \mathrm{~m}$, at the glacier terminal or in the upper branch joints. Most (14) of them disintegrated between 3400 and $3800 \mathrm{~m}$ elevation.

5.3. Changes in Glacial Area Related to Topographic Variables. To analyze the effect of topography on changes in surface area, the median elevation and mean surface slope of each glacier in the basin were calculated using SRTM DEM. It is necessary to point out that ASTER GDEM is not suited for topographic factor extraction on a changing glacial surface because its obtained date is uncertain. Figure 5(a) shows the results of comparing glacial shrinkage by dividing all glaciers into one of eight groups according to mean surface slope. The groups were divided by five-degree increments (e.g., one division might represent glaciers with $5^{\circ}$ to $10^{\circ}$ mean surface slope). Figure 5(b) compares glacial elevation to shrinkage. Glaciers 

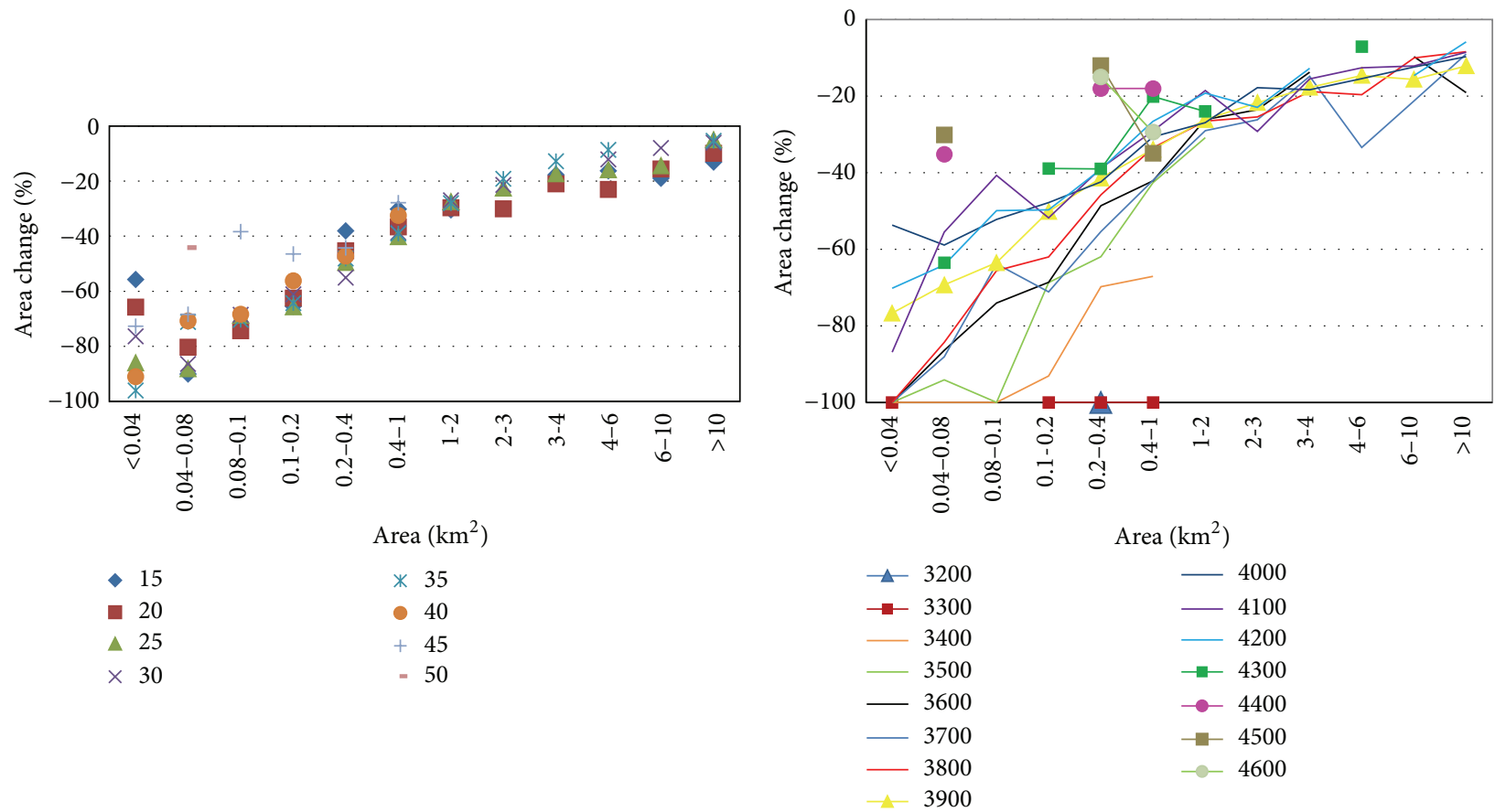

(a)

(b)

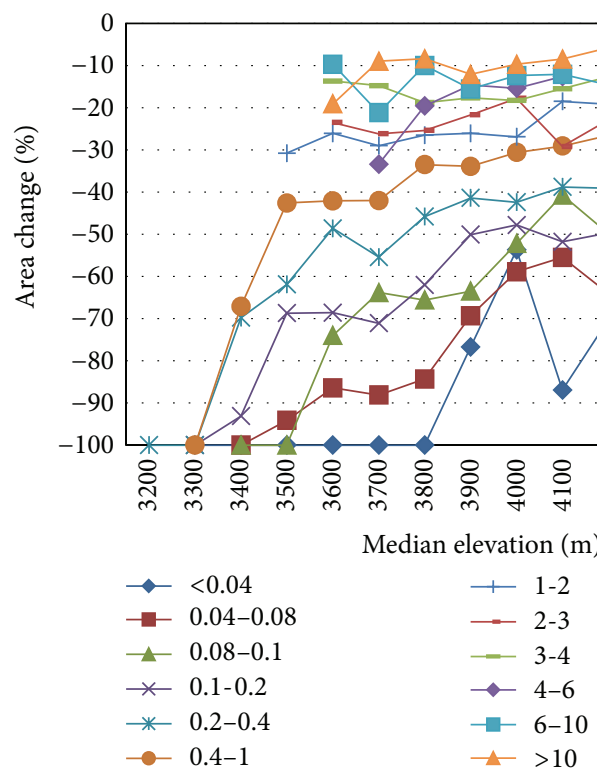

(c)

Figure 5: Glacial change in area (\%) versus mean slope, median elevation, and glacial area. (a) Glacial mean slope plotted as a function of glacial shrinkage and area, (b) glacial median elevation plotted as a function of glacial shrinkage and area, and (c) glacial area plotted as a function of glacial shrinkage and median elevation.

were divided into 15 100-meter elevation groups. For example, all glaciers with a median surface elevation between 2900 and $3000 \mathrm{~m}$ were grouped together in the $3000 \mathrm{~m}$ division. Figure 5(c) groups glaciers of similar size to compare glacial size to shrinkage.

Figure 5(a) shows that shrinkage was greater for glaciers smaller than $0.08 \mathrm{~km}^{2}$. It also shows that the slopes of large glaciers $\left(>0.08 \mathrm{~km}^{2}\right)$ had nearly no effect on shrinkage. Glaciers smaller than $0.08 \mathrm{~km}^{2}$ showed no relationship between glacial area and shrinkage.

Figure 5(b) shows a logarithmic relationship between shrinkage and area for glaciers at similar median elevations. For example, at $3700 \mathrm{~m}$ median elevation, large $\left(>1 \mathrm{~km}^{2}\right)$ glaciers experienced less shrinkage than smaller ones. 
TABLE 6: Area percentage of each area group in all subbasins in the 1960s.

\begin{tabular}{lccccc}
\hline Area $\left(\mathrm{km}^{2}\right)$ & $5 \mathrm{X} 042$ & $5 \mathrm{X} 043$ & $5 \mathrm{X} 044$ & $5 \mathrm{X} 045$ & $5 \mathrm{X} 046$ \\
\hline$<0.05$ & 0.7 & 0.33 & 0.47 & 0.21 & 0.06 \\
$0.05-0.1$ & 1.9 & 1.53 & 3.76 & 1.25 & 0.47 \\
$0.1-0.5$ & 29.74 & 13.52 & 33.85 & 14.27 & 9.48 \\
$0.5-1$ & 22.36 & 10.37 & 30.04 & 14.3 & 8.69 \\
$1-5$ & 45.3 & 36.62 & 31.88 & 44.67 & 24.92 \\
$5-10$ & & 16.72 & & 17.9 & 17.87 \\
$>10$ & & 20.91 & & 7.4 & 38.51 \\
\hline
\end{tabular}

Figure 5(c) shows that the relationship between glacial shrinkage and area is more pronounced for those larger than $1 \mathrm{~km}^{2}$. It also indicates that shrinkage in small glaciers $\left(<1 \mathrm{~km}^{2}\right)$ was greater at lower elevations whereas shrinkage in larger glaciers was less affected by elevation. Our results concur with previous research which found that lower median elevation resulted in relatively more loss in area [42]. Bolch's study did not remove the impact of glacial size, and the exact relationship was not as distinct as was found in our study [42].

In summary, in glaciers smaller than $0.08 \mathrm{~km}^{2}$, glacial recession appeared to be primarily controlled by median elevation (Figures 5(a) and 5(c)). Those between $0.08 \mathrm{~km}^{2}$ and $1 \mathrm{~km}^{2}$ showed a linear relationship between size and median elevation (Figures 5(b) and 5(c)). Shrinkage was not affected by median elevation for glaciers larger than $1 \mathrm{~km}^{2}$ (Figures 5(b) and 5(c)).

Table 6 shows that the majority of overall glacial area is concentrated in glaciers larger than $1 \mathrm{~km}^{2}$. Glaciers larger than $5 \mathrm{~km}^{2}$ accounted for over half the total glacial area in the Tekes River subbasin. Glaciers larger than $1 \mathrm{~km}^{2}$ accounted for $74.3 \%$ of the total glacial area in the Kax River subbasin and $70 \%$ of the total glacial area in the Kuksu River subbasin. Of the five subbasins, the Kunes River basin held the smallest glaciers. The distribution of glacial area in the five subbasins was consistent with their glacial changes. The larger the proportion of large glaciers $\left(>10 \mathrm{~km}^{2}\right)$, the smaller the glacial area loss. For example, glaciers in the Tekes River basin, with the largest proportion of glaciers larger than $10 \mathrm{~km}^{2}$, had the smallest area shrinkage. Consequently, the distribution of glacial area is probably one of the main factors of change for the basin scale.

Most glaciers at lower elevations disappeared during the study period. For example, $80 \%$ of those at a median elevation of less than $3400 \mathrm{~m}$ disappeared (Figure 6). Through regression analysis, Figure 6 demonstrates an exponential relationship between the percentage of disappearing glaciers and median glacial elevation. All glaciers below $3300 \mathrm{~m}$ asl disappeared, and $38 \%$ of those between $3300 \mathrm{~m}$ and $3400 \mathrm{~m}$ disappeared. Only $1 \%$ of the glaciers at a median elevation of $3800 \mathrm{~m}$ disappeared. As expected, smaller glaciers at lower elevations were the most likely to lose area or disappear.

5.4. Changes in Glacial Area Related to Debris Cover. The 2007 and 2009 maps showed that 80 glaciers were covered

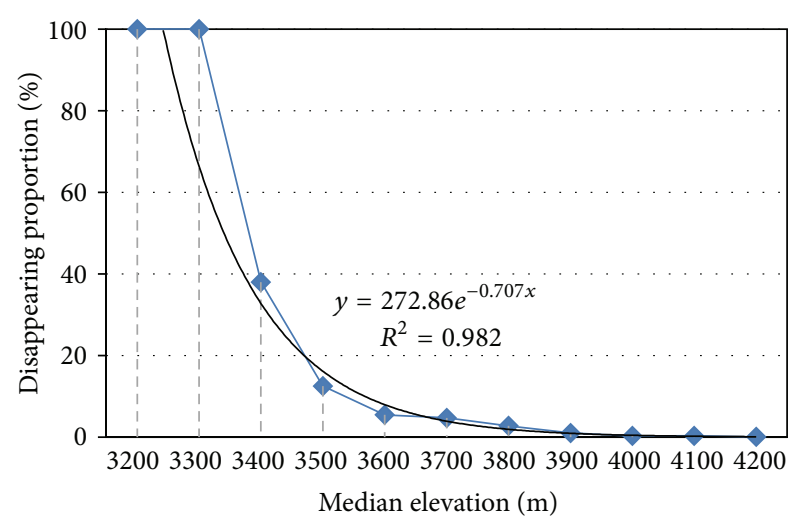

FIGURE 6: Percentage of glacial area lost by glaciers that disappeared as a function of median glacial elevation.

with debris. Compared with debris-free glaciers, these shrunk less (Figure $7(\mathrm{a})$ ). The area lost from debris-covered glaciers was between $7.5 \%$ and $20 \%$, significantly less than the area lost from debris-free glaciers. Area loss by debris-covered glaciers is smaller by $2.5 \%$ to $7.5 \%$ than clean ice of the same size. This difference becomes smaller in large glaciers. The general result is that glaciers with debris cover greater than $25 \%$ lost less surface area than the others (Figure 7(b)).

\section{Discussion}

There were no advancing or surging glaciers in the Ili River basin during the measurement periods. It is different from the Aksu catchment in the central Tian Shan Mountains where 10 advancing glaciers were found between 1990 and 2010 [49]. Our results are similar to those found for glaciers in the western Nyainqentanglha Range and the Nam Co Basin, Tibet, where also no advancing/surging was found from 1976 to 2009 [42]. Sorg et al. reported that, of the entire Tian Shan range, the outer ranges had the strongest annual area shrinkage rates since the middle of the twentieth century; they were between $0.38 \%$ and $0.76 \% \mathrm{a}^{-1}$ [50]. Thus, glaciers in the Ili River basin should show the greatest area shrinkage $\left(0.6 \% \mathrm{a}^{-1}\right)$ of the range, the same as in the glaciers of Big Naryn basin (central Tian Shan), where the area shrinkage was $23.4 \%\left(0.6 \% \mathrm{a}^{-1}\right)$ from the mid-20th century to 2007.

In many mountainous regions, various glaciers grow and shrink at different rates, and some glaciers will advance or surge while others shrink [6, 20,31]. Some studies pointed out that glaciers of different sizes respond to climate change differently because of the time lag [17, 42, 51]. Previous studies found that larger glaciers tended to shrink less, as a percentage of total area, than smaller glaciers [42, 51, 52]; our results agree. These studies also implied that small glaciers $\left(<0.4 \mathrm{~km}^{2}\right)$ were easily affected by topography, and glaciers that shrank in area or disappeared had lower mean elevations [53]. However, this research showed only the relationship between topographic settings and glaciers smaller than $0.4 \mathrm{~km}^{2}$. Our results not only showed that changes in small glaciers $\left(<1 \mathrm{~km}^{2}\right)$ are affected by topography 


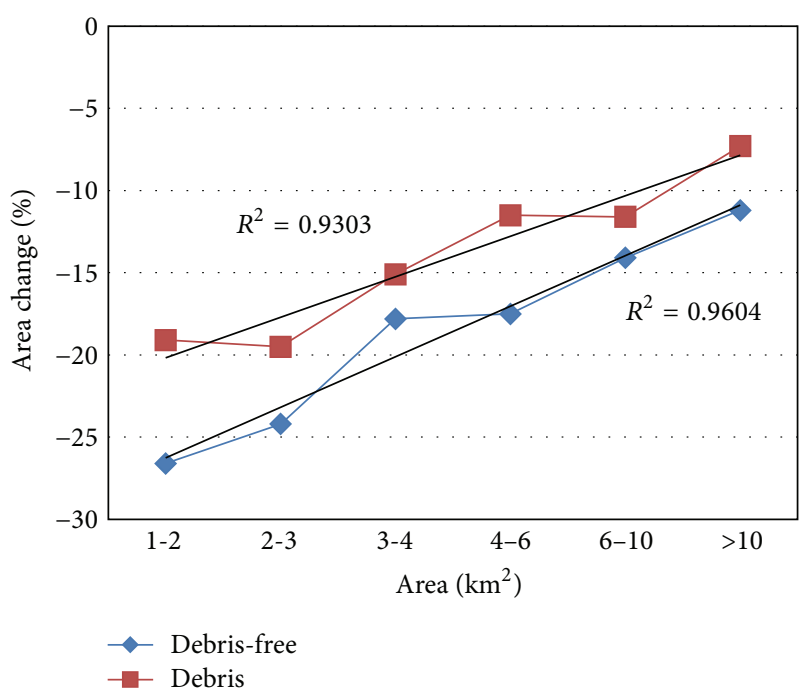

(a)

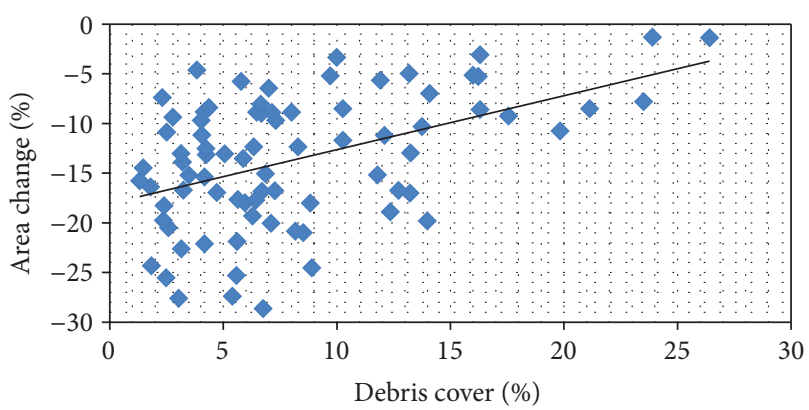

(b)

Figure 7: Area change (\%) of debris-covered glaciers. (a) Percent area shrinkage of glaciers of various sizes, debris-covered and debrisfree, and (b) percent decrease in glacial area as a function of the percentage of the glacier covered in debris.

and size together, but also showed that larger glaciers were less affected by topographic factors. These diverse factors result in a real world situation that is difficult to simulate with hydrological or land surface models.

Debris cover affects the response of glaciers to climate change by altering surface ablation rates [54, 55]. Previous research pointed out that heavily debris-covered glaciers, with stagnant low-gradient terminus regions, typically had stable fronts in the Himalayas [20]. Our results agree that debris-covered glaciers have less shrinkage than debris-free glaciers. Thus, we suggest that the vast debris cover of glaciers in the Tekes River basin is one factor that was responsible for the lower shrinkage seen there rather than in other basins. However, previous studies of debris-covered glaciers on Tomur Peak showed that thinning of debris-covered ice was not statistically different from that of debris-free ice $[19,56]$. This should not conflict with our results. Studies have shown that ice cliffs and supraglacial lakes always develop in debris-covered areas, and these cliffs result in $69 \%$ of the melting of debris-covered areas in the Himalayas [57]. These quick ablation ice cliffs could cause extensive thinning of

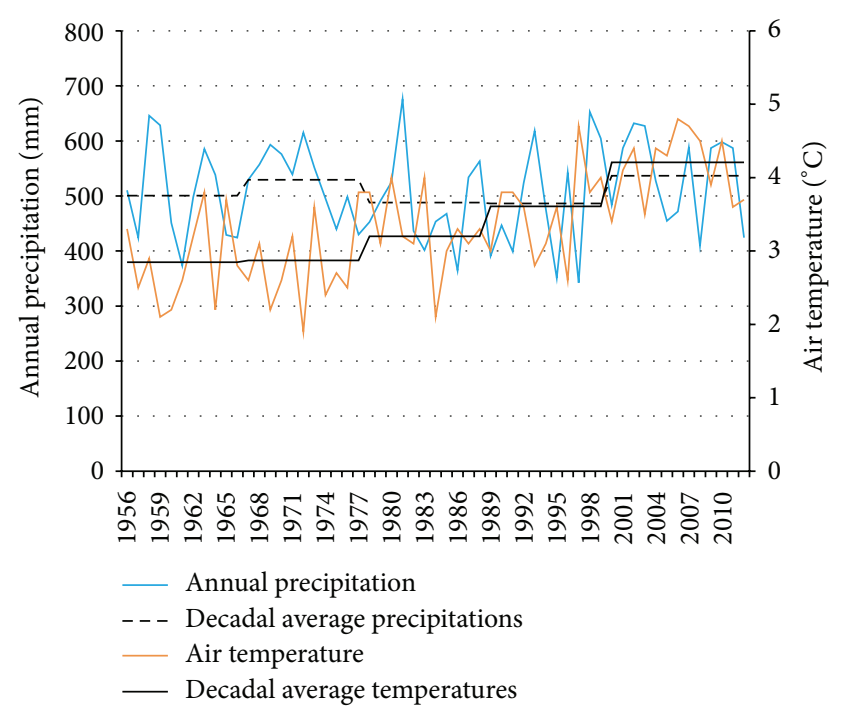

FIGURE 8: Changes in annual air temperature and precipitation between 1956 and 2012.

debris-covered ice, but the percentage of ice cliffs is small, and they can not affect the overall area shrinkage seen in debriscovered glaciers. This calls for studies of ice thickness changes in debris-covered and debris-free glaciers while observing ice cliff distribution in debris areas.

Research suggests that glacial recession is mainly influenced by global warming $[42,44,49,52]$. Meteorological data obtained from the Zhaosu weather station $\left(43.15^{\circ} \mathrm{N}, 81.133^{\circ} \mathrm{E}\right.$; $1851 \mathrm{~m}$ asl) were used to analyze the drivers of change to the glaciers in the Ili River basin (Figure 8). This station recorded a significant temperature increase between 1956 and 2012. Temperature has risen by $1.4^{\circ} \mathrm{C}$ in the past 56 years and the warming tendency has accelerated, as evidenced by the decadal average temperatures. Precipitation has slightly increased during the same period but decreased between 1978 and 1998. Thus, we suggest that glacial recession between the 1960 s and 2007/2009 can be attributed primarily to air-temperature increases, even though precipitation slightly increased at the same time. This greater precipitation could not offset ice losses resulting from surface melting driven by higher temperatures.

\section{Summary and Conclusions}

This study used multitemporal remote sensing and historical topographic maps to analyze glacial changes in the area of the Ili River. Our results updated the first glacier inventory from the 1960s by employing additional sources of data and enhanced analytical methods. The use of satellite data revealed that glaciers in the study area shrunk by $24.2 \% \pm$ $8.8 \%$ between the 1960s and 2007/2009. No expanding or advancing glaciers were identified in the study area during the same time period. The greatest glacial shrinkage occurred in the Kunes River basin, which contained most of the smaller glaciers. During the 40 -year study period, 331 glaciers disappeared, and 18 disintegrated into two or three glaciers. 
Rising temperatures resulting from global climate change are considered to be the main reason for glacial recession. Glacial sizes and elevations were determined to be control factors which determined the magnitude of response that glaciers had to climate change. The mean glacier slope showed no relationship with glacial recession and disappearance. Increases in the debris cover appeared to have a minor influence on the melting of glaciers, an effect that was more pronounced in smaller glaciers. We found that smaller glaciers lost a higher percentage of their surface area as a result of melting.

\section{Conflict of Interests}

The authors declare that there is no conflict of interests regarding the publication of this paper.

\section{Acknowledgments}

This work was supported by the Key Research Program of the Chinese Academy of Sciences (Grant no. KZZDEW-12-1), the China National Natural Science Foundation (Grant no. 41401084), the Ministry of Science and Technology of China (MOST; Grant nos. 2010DFA92720-23 and 2013FY111400), and the Strategic Priority Research ProgramClimate Change: Carbon Budget and Relevant Issues (Grant no. XDA05090302). The data applied resulted from an immediate past project from the MOST (Grant no. 2006FY110200). The authors' appreciation is also extended to NASA for the provision of the Landsat TM data and SRTM data, as well as China Meteorological Administration for climate data.

\section{References}

[1] Intergovernmental Panel on Climate Change, Climate Change 2013-The Physical Science Basis. Contribution of Working Group I to the Fifth Assessment Report of the Intergovernmental Panel on Climate Change, T. F. Stocker, D. Qin, G.-K. Plattner, Eds., Cambridge University Press, Cambridge, UK, 2013.

[2] R. G. Barry, "The status of research on glaciers and global glacier recession: a review," Progress in Physical Geography, vol. 30, no. 3, pp. 285-306, 2006.

[3] World Glacier Monitoring Service, Global Glacier Changes: Facts and Figures, 2008, http://www.grid.unep.ch/glaciers/.

[4] K. Hewitt, "Glacier change, concentration, and elevation effects in the Karakoram Himalaya, upper indus basin," Mountain Research and Development, vol. 31, no. 3, pp. 188-200, 2011.

[5] T. Bolch, A. Kulkarni, A. Kääb et al., "The state and fate of Himalayan glaciers," Science, vol. 336, no. 6079, pp. 310-314, 2012.

[6] J. L. Xu, S. Y. Liu, S. Zhang, W. Guo, and J. Wang, "Recent changes in glacial area and volume on Tuanjiefeng Peak Region of Qilian Mountains, China," PLoS ONE, vol. 8, no. 8, Article ID e70574, 2013.

[7] A. S. Trupin, M. F. Meier, and J. M. Wahr, "Effect of melting glaciers on the Earth's rotation and gravitational field: 19651984," Geophysical Journal International, vol. 108, no. 1, pp. 1-15, 1992.
[8] S. G. Evans and J. J. Clague, "Recent climatic change and catastrophic geomorphic processes in mountain environments," Geomorphology, vol. 10, no. 1-4, pp. 107-128, 1994.

[9] W. Haeberli and M. Beniston, "Climate change and its impacts on glaciers and permafrost in the Alps," Ambio, vol. 27, no. 4, pp. 258-265, 1998.

[10] J. M. Reynolds, A. Dolecki, and C. Portocarrero, "The construction of a drainage tunnel as part of glacial lake hazard mitigation at Hualcan, Cordillera Blanca, Peru," in Geohazards in Engineering Geology, vol. 15, pp. 41-48, 1998.

[11] Y. P. Sheng, H. C. Su, G. Y. Wang et al., “The response of glaciers and snow cover to climate change in Xinjiang (II): hazards effects," Journal of Glaciology and Geocryology, vol. 35, no. 6, pp. 1355-1370, 2013.

[12] W. D. Gao, M. Z. Liu, W. S. Wei et al., "The occurrence and mitigation of drifting snow and avalanche hazard in the mountains along the Jinghe-Yining railway, Tianshan, China," Journal of Mountain Science, vol. 23, no. 1, pp. 43-52, 2005.

[13] X. Wang, K. P. Wu, H. L. Jiang et al., "Wide expansion of glacial lakes in Tianshan Mountains during 1990-2010," Acta Geographica Sinica, vol. 68, no. 7, pp. 983-993, 2013.

[14] Y. He, T. B. Yang, H. Z. Tiani et al., "Response of glacier area variation to climate change in northern Tianshan Mountains in the past 23 years," Journal of Arid Land Resources and Environment, vol. 27, no. 3, pp. 53-60, 2013.

[15] I. V. Severskiy, A. L. Kokarev, S. Severskiy et al., Contemporary and Prognostic Changes of Glaciation in Balkhash Lake Basin, VAC Publishing House, Almaty, Kazakhstan, 2006.

[16] R. Jin, X. Li, T. Che, L. Wu, and P. Mool, “Glacier area changes in the Pumqu river basin, Tibetan Plateau, between the 1970s and 2001," Journal of Glaciology, vol. 51, no. 175, pp. 607-610, 2005.

[17] D. Shangguan, S. Liu, Y. Ding, L. Ding, J. Xu, and L. Jing, "Glacier changes during the last forty years in the Tarim Interior River basin, northwest China," Progress in Natural Science, vol. 19, no. 6, pp. 727-732, 2009.

[18] C. Narama, A. Kääb, M. Duishonakunov, and K. Abdrakhmatov, "Spatial variability of recent glacier area changes in the Tien Shan Mountains, Central Asia, using Corona ( 1970), Landsat ( 2000), and ALOS ( 2007) satellite data," Global and Planetary Change, vol. 71, no. 1-2, pp. 42-54, 2010.

[19] T. Pieczonka, T. Bolch, W. Junfeng, and L. Shiyin, "Heterogeneous mass loss of glaciers in the Aksu-Tarim Catchment (Central Tien Shan) revealed by 1976 KH-9 Hexagon and 2009 SPOT-5 stereo imagery," Remote Sensing of Environment, vol. 130, pp. 233-244, 2013.

[20] D. Scherler, B. Bookhagen, and M. R. Strecker, "Spatially variable response of Himalayan glaciers to climate change affected by debris cover," Nature Geoscience, vol. 4, no. 3, pp. 156-159, 2011.

[21] A. Kääb, E. Berthier, C. Nuth, J. Gardelle, and Y. Arnaud, "Contrasting patterns of early twenty-first-century glacier mass change in the Himalayas," Nature, vol. 488, no. 7412, pp. 495498, 2012.

[22] C. H. Liu and L. F. Ding, "Some comments on the glacier inventory of Ili river drainage basin in Tianshan mountains," in Glacier Inventory of China III, Tian Shan Mountains (Ili River Drainage Basin), C.A.O.S. Lanzhou Institute of Glaciology and Geocryology, Ed., pp. 1-7, Sciense Press, Peking, China, 1986.

[23] C. H. Liu, Z. C. Xie, and M. B. Dyurgerov, Glaciation in Tianshan Mountains, Science Press, Beijing, China, 1998. 
[24] Y. F. Shi, Concise Glacier Inventory in China, Shanghai Popular Science Press, 2005.

[25] Y. Zhang, K. Fujita, S. Liu, Q. Liu, and X. Wang, "Multi-decadal ice-velocity and elevation Changes of a monsoonal maritime glacier: hailuogou glacier, China," Journal of Glaciology, vol. 56, no. 195, pp. 65-74, 2010.

[26] J. X. Wang, J. Wang, and C. P. Lu, "Problem of coordinate transformation between WGS-84 and BEIJING 54," Journal of Geodesy of Geodynamic, vol. 23, no. 3, pp. 70-73, 2003.

[27] Y. J. Gao and D. F. Zhang, "The conversion method and accuracy analysis between WGS-84 coordinate system and Xian 80 coordinate system," Engineering of Surveying and Mapping, vol. 18, pp. 55-57, 2009.

[28] G. D. Liu, Y. Q. Zhao, Z. L. Wang et al., "The conversion method and accuracy analysis between Xian 1980 and WGS-84 coordinate system," Geomatics \& Spatial Information Technology, vol. 29, pp. 40-41, 2006.

[29] R. S. Williams Jr., D. K. Hall, O. Sigurbsson, and J. Y. L. Chien, "Comparison of satellite-derived with ground-based measurements of the fluctuations of the margins of Vatnajökull, Iceland, 1973-92," Annals of Glaciology, vol. 24, pp. 72-80, 1997.

[30] H. Rott, "Thematic studies in alpine areas by means of polarimetric SAR and optical imagery," Advances in Space Research, vol. 14, no. 3, pp. 217-226, 1994.

[31] D. Shangguan, S. Liu, Y. Ding, L. Ding, and G. Li, “Glacier changes at the head of Yurungkax River in the West Kunlun Mountains in the past 32 years," Acta Geographica Sinica, vol. 59, no. 6, pp. 855-862, 2004.

[32] J. L. Xu, S. Y. Liu, S. Q. Zhang et al., "Glaciers fluctuations in the Karamilan-Keriya River Watershed in the past 30 years," Journal of Glaciology and Geocryology, vol. 28, no. 3, pp. 312-318, 2006.

[33] Z. Li, W. Sun, and Q. Z. Zeng, "Measurements of glacier variation in the Tibetan Plateau using landsat data," Remote Sensing of Environment, vol. 63, no. 3, pp. 258-264, 1998.

[34] F. Paul, "Changes in glacier area in Tyrol, Austria, between 1969 and 1992 derived from Landsat 5 thematic mapper and Austrian Glacier Inventory data," International Journal of Remote Sensing, vol. 23, no. 4, pp. 787-799, 2002.

[35] R. Bhambri, T. Bolch, and R. K. Chaujar, "Mapping of debriscovered glaciers in the Garhwal Himalayas using ASTER DEMs and thermal data," International Journal of Remote Sensing, vol. 32, no. 23, pp. 8095-8119, 2011.

[36] F. Paul, C. Huggel, and A. Kääb, "Combining satellite multispectral image data and a digital elevation model for mapping debris-covered glaciers," Remote Sensing of Environment, vol. 89, no. 4, pp. 510-518, 2004.

[37] R. Ranzi, G. Grossi, L. Iacovelli, and S. Taschner, "Use of multispectral ASTER images for mapping debris-covered glaciers within the GLIMS project," in Proceedings of the IEEE International Geoscience and Remote Sensing Symposium (IGARSS '04), vol. 2, pp. 1144-1147, Anchorage, Alaska, USA, September 2004.

[38] A. Shukla, M. K. Arora, and R. P. Gupta, "Synergistic approach for mapping debris-covered glaciers using optical-thermal remote sensing data with inputs from geomorphometric parameters," Remote Sensing of Environment, vol. 114, no. 7, pp. 13781387, 2010.

[39] M. Shahgedanova, G. Nosenko, S. Kutuzov, O. Rototaeva, and T. Khromova, "Deglaciation of the Caucasus Mountains, Russia/ Georgia, in the 21st century observed with ASTER satellite imagery and aerial photography," The Cryosphere, vol. 8, no. 6, pp. 2367-2379, 2014.
[40] W. Q. Guo, S. Y. Liu, P. C. Yu et al., "Automatic extraction of ridgelines using on drainage boundaries and aspect difference," Science of Surving and Mapping, vol. 36, no. 6, pp. 210-212, 2011.

[41] D. K. Hall, K. J. Bayr, W. Schöner, R. A. Bindschadler, and J. Y. L. Chien, "Consideration of the errors inherent in mapping historical glacier positions in Austria from the ground and space (1893-2001)," Remote Sensing of Environment, vol. 86, no. 4, pp. 566-577, 2003.

[42] T. Bolch, T. Yao, S. Kang et al., "A glacier inventory for the western Nyainqentanglha range and the Nam Co Basin, Tibet, and glacier changes 1976-2009," Cryosphere, vol. 4, no. 3, pp. 419-433, 2010

[43] D. H. Shangguan, S. Y. Liu, Y. J. Ding et al., "Glacier changes in the Koshi River basin, central Himalaya, from 1976 to 2009, derived from remote-sensing imagery," Annals of Glaciology, vol. 55, no. 66, pp. 61-68, 2014.

[44] G. L. Zhang, B. T. Pan, J. Wang et al., "Research on the glacier change in the Gongga Mountain based on remote-sensing and GPS from 1966 to 2008," Journal of Glaciology and Geocryology, vol. 32, no. 3, pp. 454-460, 2010.

[45] Y. W. Zeng, "Accuracy analysis of map scanning digitization," Surveying and Mapping of Sichuan Province, vol. 26, no. 3, pp. 82-85, 2003.

[46] A. E. Racoviteanu, F. Paul, B. Raup, S. J. S. Khalsa, and R. Armstrong, "Challenges and recommendations in mapping of glacier parameters from space: results of the 2008 global land ice measurements from space (GLIMS) workshop, Boulder, Colorado, USA," Annals of Glaciology, vol. 50, no. 53, pp. 53-69, 2009.

[47] T. Bolch, B. Menounos, and R. Wheate, "Landsat-based inventory of glaciers in western Canada, 1985-2005," Remote Sensing of Environment, vol. 114, no. 1, pp. 127-137, 2010.

[48] W. Q. Guo, S. Y. Liu, J. L. Xu, and et al, "The second Chinese glacier inventory: data, methods and results," Journal of Glaciology, vol. 61, no. 226, pp. 357-372, 2015.

[49] A. Osmonov, T. Bolch, C. Xi, A. Kurban, and W. Guo, "Glacier characteristics and changes in the Sary-Jaz River Basin (Central Tien Shan, Kyrgyzstan)-1990-2010," Remote Sensing Letters, vol. 4, no. 8, pp. 725-734, 2013.

[50] A. Sorg, T. Bolch, M. Stoffel, O. Solomina, and M. Beniston, "Climate change impacts on glaciers and runoff in Tien Shan (Central Asia)," Nature Climate Change, vol. 2, no. 10, pp. 725731, 2012.

[51] J. L. Xu, S. Q. Zhang, and D. H. Shangguan, "Glacier change in head water of the Yangze river in recent three decades," Arid Zone Research, vol. 35, no. 5, pp. 919-926, 2013.

[52] D. H. Shangguan, S. Y. Liu, Y. J. Ding et al., "Changes in the elevation and extent of two glaciers along the Yanglonghe river, Qilian Shan, China," Journal of Glaciology, vol. 56, no. 196, pp. 309-317, 2010.

[53] C. M. DeBeer and M. J. Sharp, "Topographic influences on recent changes of very small glaciers in the monashee mountains, British Columbia, Canada," Journal of Glaciology, vol. 55, no. 192, pp. 691-700, 2009.

[54] M. Nakawo, H. Yabuki, and A. Sakai, "Characteristics of Khumbu Glacier, Nepal Himalaya: recent change in the debriscovered area," Annals of Glaciology, vol. 28, pp. 118-122, 1999.

[55] Y. Takeuchi, R. B. Kayastha, and M. Nakawo, "Characteristics of ablation and heat balance in debris-free and debriscovered areas on Khumbu Glacier, Nepal Himalayas, in the premonsoon season," Debris-Covered Glaciers, no. 264, pp. 53-61, 2000 . 
[56] G. X. Ding, C. P. Chen, C. W. Xie et al., "Study of the ice tongue ablation features of a large glacier in the south slopes of the Mt. Tuomuer in the Tianshan mountains," Journal of Glaciology and Geocryology, vol. 36, no. 1, pp. 20-29, 2014.

[57] A. Sakai, M. Nakawo, and K. Fujita, "Melt rate of ice cliffs on the Lirung glacier, Nepal Himalayas, 1996," Bulletin of Glacier Research, vol. 16, pp. 57-66, 1998. 

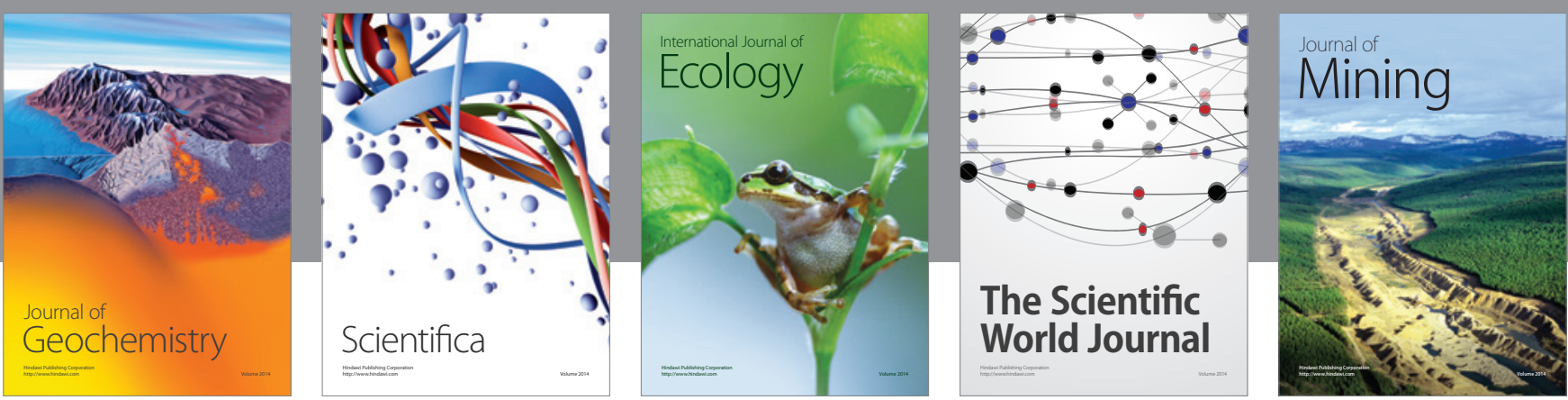

The Scientific World Journal
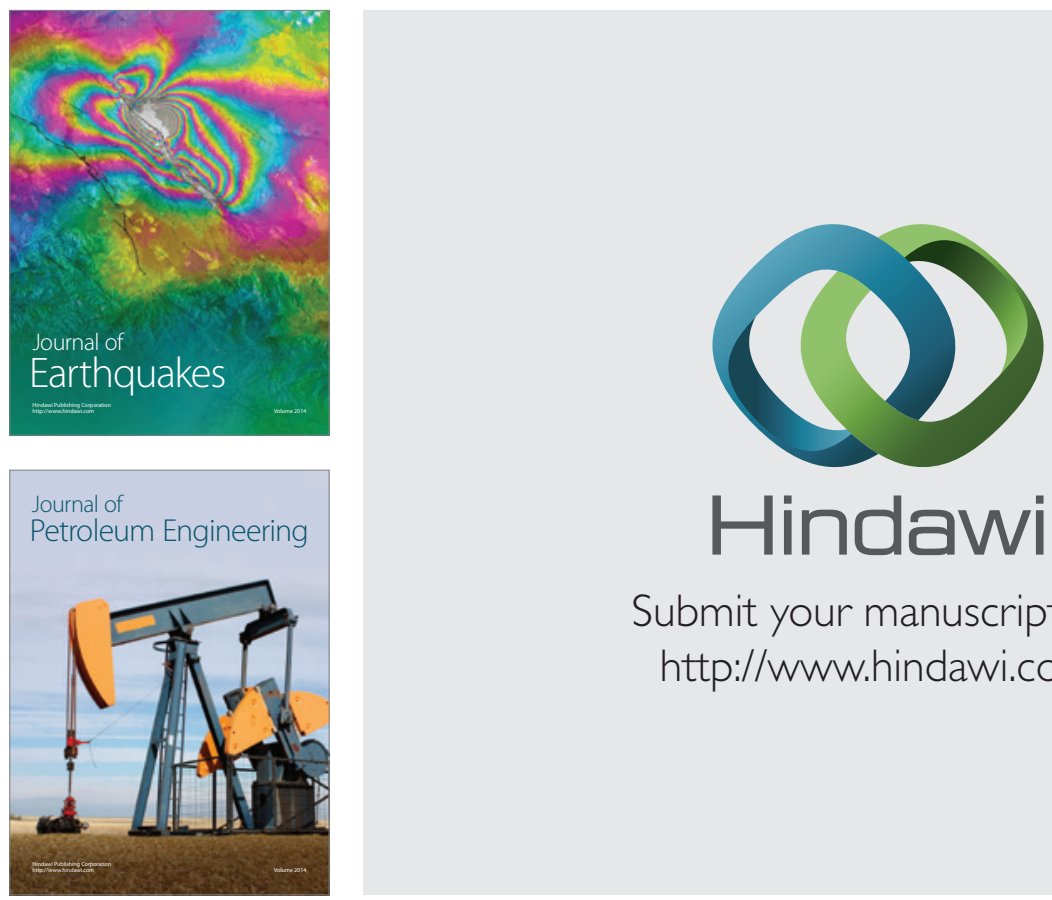

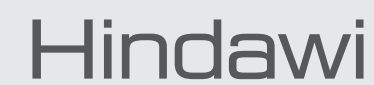

Submit your manuscripts at

http://www.hindawi.com
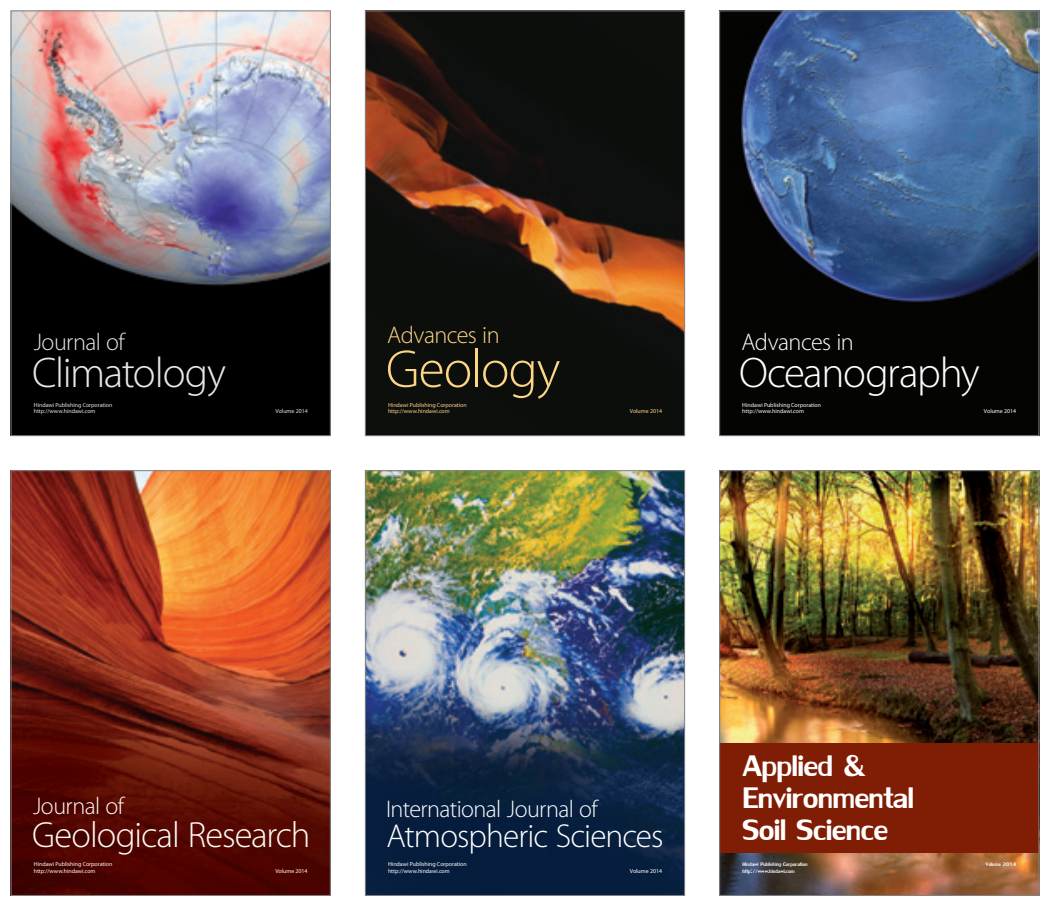
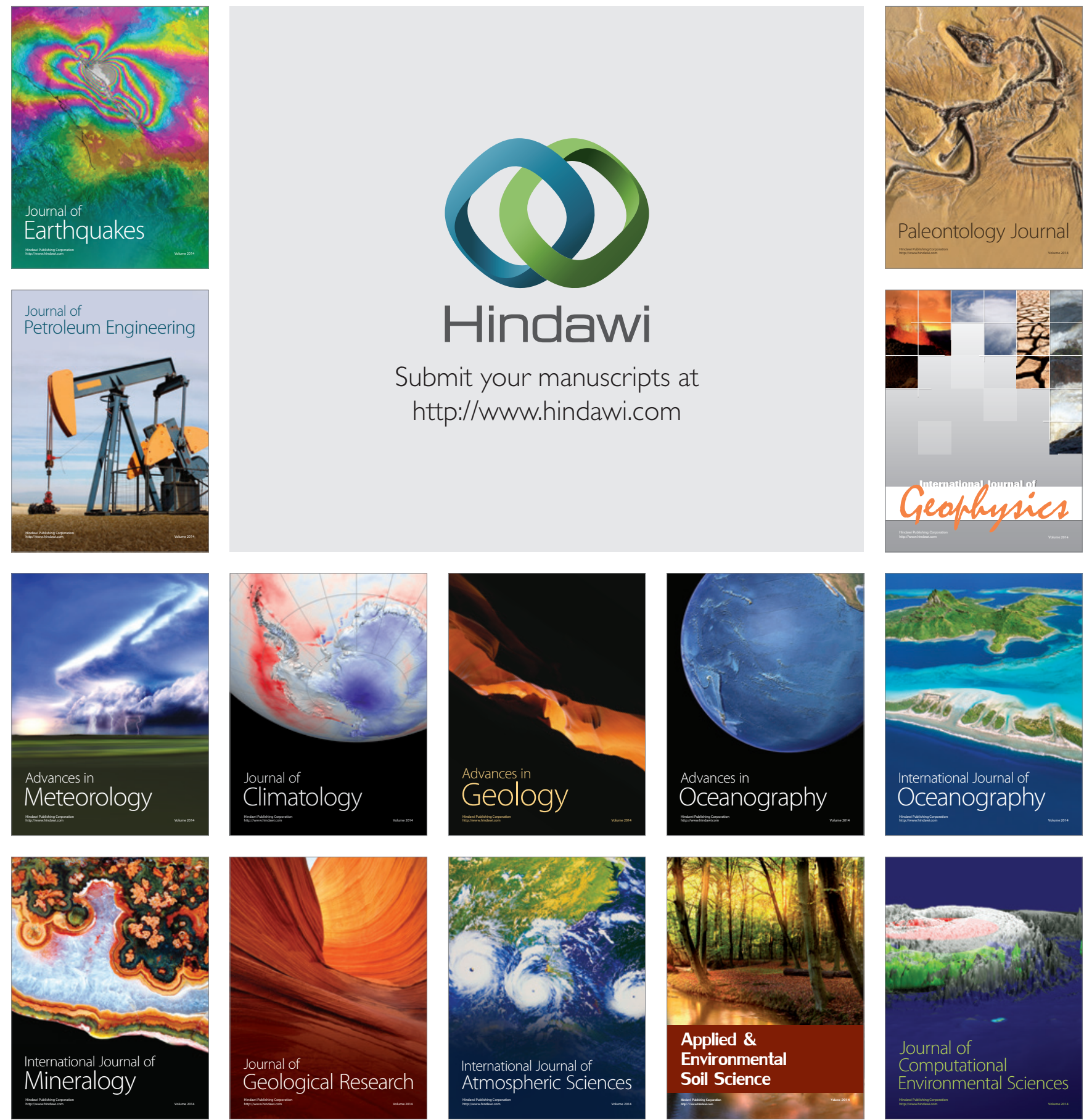